\title{
An Emerging and Valuable Trendson Rare Earth Silicate Based Different Colours Light Emitting Phosphors - A Review
}

\author{
Shashank Sharma ${ }^{1}$ | Sanjay Kumar Dubey ${ }^{2}$ | A K Diwakar ${ }^{3}$
}

1,*Ph.D. Research Scholar, Department of Physics, Kalinga University Atal Nagar New Raipur 492101, Chhattisgarh, India. ${ }^{2}$ Ph.D. Research Scholar, Department of Physics, Kalinga University Atal Nagar New Raipur 492101, Chhattisgarh, India. ${ }^{3}$ Associate professor, Department of Physics, Kalinga University Atal Nagar New Raipur 492101, Chhattisgarh, India.

\section{To Cite this Article}

Shashank Sharma, Sanjay Kumar Dubey and A K Diwakar, "An Emerging and Valuable Trendson Rare Earth Silicate Based Different Colours Light Emitting Phosphors - A Review", International Journal for Modern Trends in Science and Technology, Vol. 06, Issue 06, June 2020, pp.:121-124; https://doi.org/10.46501/IJMTST060626

Article Info

Received on 12-May-2020, Revised on 04-June-2020, Accepted on 07-June-2020, Published on 15-June-2020.

\section{ABSTRACT}

In this present review paper, which deals on these emerging research areas indicated that deep studied the concept of rare earth doped silicate material with different colour Light emitting phosphors. We find that reliability analysis on photo luminescence properties of different colour LED's Emission and excitation spectra with different wavelength. An application in various branches that can be better futuristic Scopes improvement. With this vision we are used new nano materials also built a suitable learning environmental and low-cost LED's for all the aspects regarding use of new advanced technology in conformity with demand of present society

KEYWORDS: Photo luminescence, mechano luminescence, photonics, Laser, UV, VUV,LED's (Light Emitting diodes).

Copyright (C) 2014-2020 International Journal for Modern Trends in Science and Technology

DOI: https://doi.org/10.46501/IJMTST060626

\section{INTRODUCTION}

Today, innovations in rare earth doped long persistent phosphors are having wide ranging revolution across numerous economic and social impacts on modern society. Required work would be valuable for both social policies and unique nanotechnology design. As we know proper quality in science for humanity is not expected unless the quality of research in science for humanity is improved. Technological Lighting colours are individual part in our modern scenario.we can say that the new growing light products market generates due to great applications in optical light signs, optical printing, display board, advertising banners and decoration. among others. Rare earth metal (Ca,Sr) Silicate based structured
$\left(\mathrm{Ca}_{2} \mathrm{MgSi}_{2} \mathrm{O}_{7}\right.$ and $\left.\mathrm{Sr}_{2} \mathrm{MgSi}_{2} \mathrm{O}_{7}\right)$, new type phosphors which is called akermanite. These properties have been shown to excellent effect on a living organism which used in tissue engineering and good morphology [7]. The two new Lanthanide elements are widely used as heavily doped with silicate phosphors. Basically, Erbium and Terbium are more valuable and more efficient rare earth materials. Lanthanide elements are situated to downward in modern periodic table from Lanthanum (57) to Lutetium (71). Lanthanide ions as good activator, properties have now well-developed beneficial origin of Luminescence [8]. New Generations are very advanced. LED's are more capable and most significant part in our new life style. It is cheaper and low costs which have 
seen more beautiful and wonderful lighting colours. The present investigations review paper to great achievements and development on rare earth doped silicate based nanocrystalline and microcrystalline phosphors. Basically, new type ofLight emitting phosphors has been studied

\begin{tabular}{|l|c|c|l|l|}
\hline $\begin{array}{c}\text { Lanthanide } \\
\text { Symbol }\end{array}$ & $\begin{array}{c}\text { Lanthanide } \\
\text { Symbol }\end{array}$ & $\begin{array}{c}\text { Atomic } \\
\text { Number }\end{array}$ & $\begin{array}{c}\text { Electronic } \\
\text { Ground State }\end{array}$ & $\begin{array}{c}\text { Electronic } \\
\text { Excited State } \\
(\mathbf{R E})^{3+}\end{array}$ \\
\hline Lanthanum & $\mathrm{La}$ & 57 & {$[\mathrm{Xe}] 4 \mathrm{f}^{0} 5 \mathrm{~d}^{1} 6 \mathrm{~s}^{2}$} & {$[\mathrm{Xe}] 4 \mathrm{f}^{0}$} \\
\hline Cerium & $\mathrm{Ce}$ & 58 & {$[\mathrm{Xe}] 4 \mathrm{f}^{1} 5 \mathrm{~d}^{1} 6 \mathrm{~s}^{2}$} & {$[\mathrm{Xe}] 4 \mathrm{f}^{1}$} \\
\hline Praseodymium & $\mathrm{Pr}$ & 59 & {$[\mathrm{Xe}] 4 \mathrm{f}^{3} 6 \mathrm{~s}^{2}$} & {$[\mathrm{Xe}] 4 \mathrm{f}^{2}$} \\
\hline Neodymium & $\mathrm{Nd}$ & 60 & {$[\mathrm{Xe}] 4 \mathrm{f}^{4} 6 \mathrm{~s}^{2}$} & {$[\mathrm{Xe}] 4 \mathrm{f}^{3}$} \\
\hline Promethium & $\mathrm{Pm}$ & 61 & {$[\mathrm{Xe}] 4 \mathrm{f}^{5} 6 \mathrm{~s}^{2}$} & {$[\mathrm{Xe}] 4 \mathrm{f}^{4}$} \\
\hline Samarium & $\mathrm{Sm}$ & 62 & {$[\mathrm{Xe}] 4 \mathrm{f}^{6} 6 \mathrm{~s}^{2}$} & {$[\mathrm{Xe}] 4 \mathrm{f}^{5}$} \\
\hline Europium & $\mathrm{Eu}$ & 63 & {$[\mathrm{Xe}] 4 \mathrm{f}^{7} 6 \mathrm{~s}^{2}$} & {$[\mathrm{Xe}] 4 \mathrm{f}^{6}$} \\
\hline Gadolinium & $\mathrm{Gd}$ & 64 & {$[\mathrm{Xe}] 4 \mathrm{f}^{7} 5 \mathrm{~d}^{1} 6 \mathrm{~s}^{2}$} & {$[\mathrm{Xe}] 4 \mathrm{f}^{7}$} \\
\hline Terbium & $\mathrm{Tb}$ & 65 & {$[\mathrm{Xe}] 4 \mathrm{f}^{9} 6 \mathrm{~s}^{2}$} & {$[\mathrm{Xe}] 4 \mathrm{f}^{8}$} \\
\hline Dysprosium & $\mathrm{Dy}$ & 66 & {$[\mathrm{Xe}] 4 \mathrm{f}^{10} 6 \mathrm{~s}^{2}$} & {$[\mathrm{Xe}] 4 \mathrm{f}^{9}$} \\
\hline Holmium & $\mathrm{Ho}$ & 67 & {$[\mathrm{Xe}] 4 \mathrm{f}^{11} 6 \mathrm{~s}^{2}$} & {$[\mathrm{Xe}] 4 \mathrm{f}^{10}$} \\
\hline Erbium & $\mathrm{Er}$ & 68 & {$[\mathrm{Xe}] 4 \mathrm{f}^{12} 6 \mathrm{~s}^{2}$} & {$[\mathrm{Xe}] 4 \mathrm{f}^{\mathrm{Il}}$} \\
\hline Thulium & $\mathrm{Tm}$ & 69 & {$[\mathrm{Xe}] 4 \mathrm{f}^{13} 6 \mathrm{~s}^{2}$} & {$[\mathrm{Xe}] 4 \mathrm{f}^{12}$} \\
\hline Ytterbium & $\mathrm{Yb}$ & 70 & {$[\mathrm{Xe}] 4 \mathrm{f}^{14} 6 \mathrm{~s}^{2}$} & {$[\mathrm{Xe}] 4 \mathrm{f}^{13}$} \\
\hline Lutetium & $\mathrm{Lu}$ & 71 & {$[\mathrm{Xe}] 4 \mathrm{f}^{14} 5 \mathrm{~d}^{1} 6 \mathrm{~s}^{2}$} & {$[\mathrm{Xe}] 4 \mathrm{f}^{14}$} \\
\hline
\end{tabular}

Luminescent $\left(\mathrm{Tb}^{3+}\right)$ doped Calcium aluminosilicate powders were prepared by combustion method. $4 \mathrm{f}-4 \mathrm{f}$ electronic transitions originating from energy states ${ }^{5} \mathrm{D}_{3}$ and ${ }^{5} \mathrm{D}_{4}$ of $\mathrm{Tb}^{3+}$ were obtained under UV excitation spectral wavelength at $355 \mathrm{~nm}$. To be tuned green to white emission was observed by efficiently able to be adjusted trivalent terbium doped phosphors, respectively, tuning effect will be discussed [9]. These time researchers are investigating and finding more possibilities to rare earth material specially, new type Erbium and terbium doped silicate phosphors-based LED'sdevices.

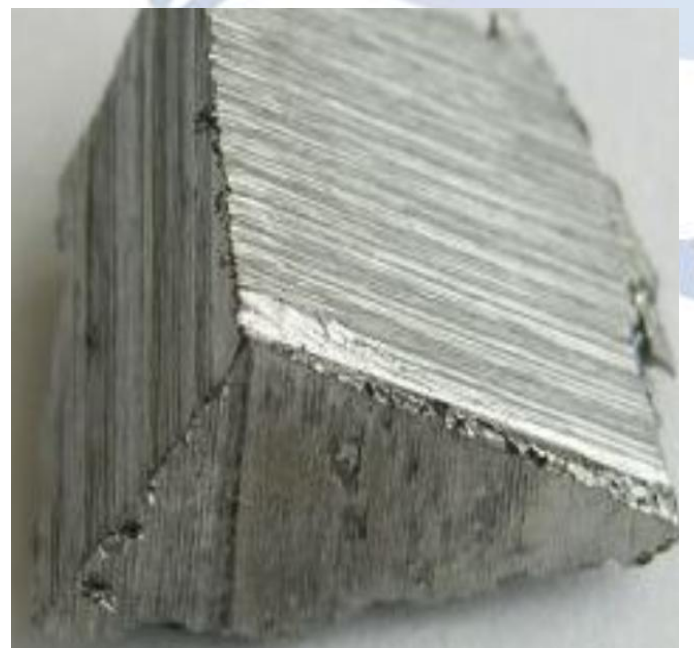

Erbium Metal

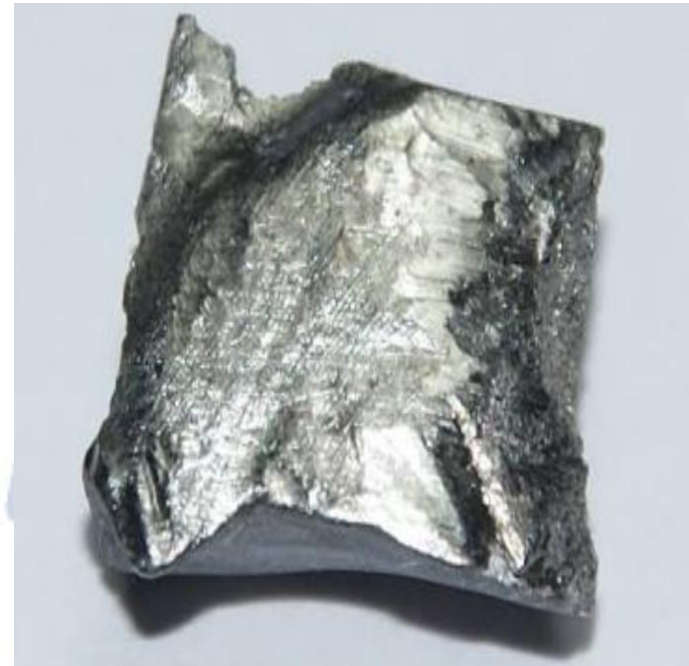

Terbium Metal

\section{SIGNIFICANCE OF RARE EARTHS}

Rare earth materials, specially Europium, dysprosium, erbium, terbium, cerium, ytterbium and gadolinium are more valuable and significant which used in light emitting diode lighting devices. Trivalent Erbium doped host materials are more wide-ranging research areawhich consists glass plate and Laser applications.For more valuable applications are widely used to Erbium doped host materials. Basically, Erbium doped fibre optical properties are used in telecommunication application in modern technology for new advanced generation [10-11].

Trivalent erbium doped glass displays intense green and a weak red emission light under 380nm excitation wavelength.

The discovery of photonics and laser applications are any glass system which is proved that the width of gain shifted to the shorter wavelength.Cross relaxation process which phenomenon is developed and used in terbium doped semiconductors and insulators. For the reason of $\mathrm{Tb}-\mathrm{Tb}$ interactions, increases the ${ }^{5} \mathrm{D}_{4}$ (green) emission of terbium ions at the expense of losing of ${ }^{5} \mathrm{D}_{3}$ (blue) luminescence intensity [12].

The role of white light LED's is established to emerging trends in new field of luminescence. White light LED's are more properties and good qualities of longer brightness, more reliable, long life time, more compactness, capable, eco-friendly, cheaper and high energy efficient [13-14].

Specially, advanced materials which is widely used for new generation of light formation. Divalent Europium doped alkaline rare earth orthosilicate structured $\mathrm{Sr}_{2} \mathrm{SiO}_{4}: \mathrm{Eu}^{2+}$ phosphor is widely observed [15-19]. 


\section{OBJECTIVES}

This study will be made by following points. The present investigation till be made with respect to Preparation of microcrystalline and nanocrystalline trivalent rare earth erbium doped calcium magnesium silicate-based phosphors, which is Characterization of above prepared phosphors and optical properties will be measured photoluminescence, mechanoluminescence and thermoluminescence and crystal structure measured through XRD.

\section{LITERATURE REVIEW}

In recent years, the luminescent properties of rare earth doped silicate materials have been widely investigated because these materials have been several advantages such as excellent high thermal intense light emission, and chemical stability. Basically, several rare earth $\mathrm{Eu}^{2+}, \mathrm{Ce}^{3+}$ and $\mathrm{Mn}^{2+}$ co-doped silicate phosphors have been investigated, such as $\mathrm{Ba}_{3} \mathrm{MgSi}_{2} \mathrm{O}_{8}: \mathrm{Eu}^{2+}, \mathrm{Mn}^{2+}$, $\mathrm{MgYSi}_{2} \mathrm{O}_{5} \mathrm{~N}: \mathrm{Ce}^{3+}, \quad \mathrm{Mn}^{2+}, \quad \mathrm{CaSiO}_{3}: \mathrm{Eu}^{2+}, \quad \mathrm{Mn}^{2+}$ $\mathrm{Ca}_{3} \mathrm{Al}_{2} \mathrm{Si}_{2} \mathrm{O}_{8} \mathrm{Cl}_{4}: \mathrm{Eu}^{2+}, \mathrm{Mn}^{2+}$ [20-23]. Silicate based materials are very improved which used in the chemical intense occurs a system is in its lowest energy state.

We have greater achievements since 2011, which have investigated silicate-based bio ceramics are promising candidates as vitro and vivo type biomaterials for tissue engineering.

The combustion synthesis method used for the morphology and crystal size ofakermanite $\left(\mathrm{Ca}_{2} \mathrm{MgSi}_{2} \mathrm{O}_{7}\right.$ and $\left.\mathrm{Sr}_{2} \mathrm{MgSi}_{2} \mathrm{O}_{7}\right)$ type silicate phosphors [24]. The new type erbium and terbium doped akermanite phosphors has been studied and significance of this new light emitting phosphors.

Since 2018, trivalent erbium doped yttrium silicate powders prepared by combustion synthesis method and investigation that the effect of $\mathrm{Mg}^{2+}$ on its structural and luminescence emission spectral characteristics for application in near infrared region. Surface morphology and structure of the powders were investigated by XRD, SEM, FTIR, Raman Spectroscopy. CW laser excitation spectral wavelength at $532 \mathrm{~nm}$ in the visible region generated in near Infrared emission [25]. Earlier, conventional combustion synthesis method has been greatly investigated for preparation of various silicate powders.

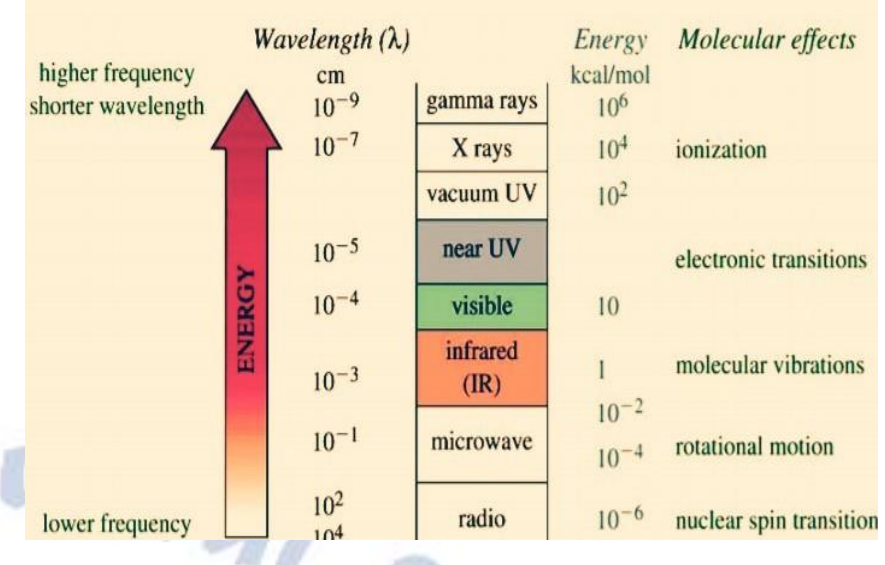

Since 2012, have also investigated that the optical characteristics like photoluminescence and afterglow properties of $\mathrm{Sr}_{2} \mathrm{SiO}_{4}$ doped with $\mathrm{Eu}^{2+}$ and $\mathrm{Dy}^{3+}$ which is the origination of the monoclinic phase of this ortho-silicate are expessed and the influenced to the crystallographic structure mitigation on the luminescence and afterglow properties under wavelength in UV and VUV excitation spectra and clearly discussed of this yellow afterglow material which insight in factors limiting the efficiency [26].

The progressive achievement in the development of mechanoluminescent devices in recent years, have motivated the fundamental research to obtain a better understanding of the behaviour of mechanoluminescent materials. Many investigations and several studies are necessary for producing the theoretical and experimental approaches background to improvement the performance of devices and discovered new mechanoluminescent devices [27].

\section{RESEARCH METHODOLODY}

The method for preparation of trivalent erbium doped calcium magnesium-based phosphor via combustion synthesis method will be used. Analytical regent grade materials are used in this synthesis process a mixture of respective metal nitrates, flux and combustion agent will be thermally treated with slight modification at various temperature for about few $\mathrm{min}$. and product sample will be annealed to different temperature and X-ray diffraction, FTIR, SEM will be used for the characterization, determination size of nanoparticles and morphology. Prepared material will be investigated for their photoluminescence characteristics using spectrofluorometer. Photoluminescence and afterglow decay properties will be measured will be irradiated to $305 \mathrm{~nm}$ over high intense emission 
wavelength in ultra violet region by Photo Multiplier Tube (PMT) or spectro fluoro meter.

\section{CONCLUSION}

This review paper to study focused on very excellent possibilities to the synthesis of trivalent erbium doped calcium magnesium silicate based micro and nano phosphor synthesis process mechanism to improvisation to the properties of crystal structure, characteristics, Emission and Excitation spectra, good features, different colour LEDs and much better possibilities. Finding applications are optical lighting devices depend conditions by a magnitude of high thermal intense emission wavelength. The various acceptations of photoluminescence and mechanoluminescene study clearly offered to new challenging and providing problems to optical display and lighting devices for the researchers, scientists and technologists.

\section{REFERENCES}

[1] Park J K, Jung MK, Kang SM, Masaki TM, Yoon DH. J. Phys. Chem. Solids, 69, 1505, 2008.

[2] Rosa I L V, Marques A P A, Tanaka M T S, Motta F V, Varela J A, Leite E R, Longo E. J. Fluorescence, 19, 495, 2009.

[3] He, H, Fu, R.; Song, X.LI, R; Pan, Z.; Zhao, X.; Deng, Z.; Cao, Y.J.Electrochem. Soc.157,3,69-73, 2010.

[4] M.S. Shurand, A.Zukauskas, Proc.IEEE, 93,1691,2005.

[5] G. Fasol and S. Nakamura, Springer, Berlin 1997.

[6] E.F. Schubert and J.K. Kim, Science,308, 1274,2005.

[7] Bhatkar V Band Bhatkar N V,Indian Academy of Sciences,Bull. Mater. Sci., Vol. 34, No. 6, 1281-1284, 2011.

[8] B.P. Chandra, S.K. Mahobia, P. Jha, R.K. Kuraria, S.K. Kurariya, R.N. Baghel, S. Thakur, J. Lumin.128, 2038, 2008.

[9] NikiforRakhov, Glauco s Maciel, J. Luminescence 190, 249-253, 2017.

[10] A.M. Hamzaa, M.K. Halimaha, F.D. Muhammada, K.T. Chana, Journal of Luminescence 207, 497-506, 2019.

[11] A. Maaoui, M. Haouari, A. Bulou, B. Boulard, H. Ben Ouada, J. Lumin. 196(1-10), May 2017, 2018.

[12] Felix Benz, Horst P. Strunk, Jakob Schaab, Journal of Applied Physics 114, 073518, 2013.

[13] S. Yao, D. Chen., Opt. Laser Technol., 40, 466, 2008.

[14] R. J. Xie, H. Naoto, M. Mamoru, S. Ken, K. Naoki,J.Appli-phys. Lett. 89, 241103, 2006.

[15] S.H.M. Poort., W. Janssen., G. Blasse, J. Alloys. Compd., 93, 260, 1997.

[16] S.H.M. Poort., J. Alloys. Compd.,75, 241,1996.

[17] J.K. Park, M.A. Lim, C.H. Kim, H.D. Park, J.T. Park, S.Y. Choi, J. Appli. Phys. Lett. 82, 683, 2003.

[18] J.S. Kim, Y.H. Park, J.C. Choi, H.L. Park, J. Electro chem. Soc. 152, H 135, 2005.

[19] J.S. Kim, K.J. Choi, S.H. Park, J. Electro chem. Soc. 152, H 121,2005

[20] Suli Wu, Shufen Zhang, Jinzong Yang, Materials Chemistry and Physics 102: 80-85, 2007.
[21] Zhang G.B., Qi Z.M., Zhou H. J., Fua Y. B., HuoaT.L., Luob, X.X, Shi C.S., Journal of Electron Spectroscopy and Related Phenomena 144-147: 861-863, 2005.

[22] Zhang Xinguo, and Gong Menglian, Journal of Alloys and Compounds 509:2850-2855, 2011.

[23] Shan Huang, Xiantao Wei, Yonghu Chen, Min Yin, Journal of rare earths, Vol. 31, No. 3, P. 227, 2013.

[24] Bhatkar V Band Bhatkar N V, Bull. Mater. Sci., Vol. 34, No. 6, 1281-1284, 2011.

[25] Nikiforrakov, Renato B Guimaraes, glauco s maciel, Journal of alloys and compounds 735, 1628-1636, 2018.

[26] Dutczak Danuta, Milbrat Alexander, Katelnikovas Arturas, MeijerinkAndries, Ronda Cees, Justel Thomas, Journal of Luminescence 132: 2398-2403, 2012.

[27] B.P.Chandra, V. K. Chandra, Piyush Jha, J. Luminescence 135:139-153, 2013. 